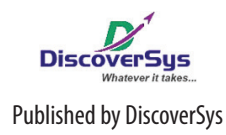

Published by DiscoverSys

\title{
Healthy tourism initiatives at destinations: opportunities and challenges
}

\author{
I Made Ady Wirawan
}

${ }^{1}$ Department of Public Health and Preventive Medicine, Faculty of Medicine, Udayana University
*Correspondence to:

I Made Ady Wirawan

ady.wirawan@gmail.com
The Indonesian Government Regulation number 67 in 1996 on the Organization of Tourism stated that tourism involves traveling activities to tourism destination. In addition, tourism is defined as anything related to travel including businesses in tourism destination and other supporting industries. ${ }^{1}$

Understanding the definition is important because sciences and practices related to medicine and health at tourism areas have developed rapidly. This can be applied to identify scopes and appropriate components for each sub discipline. Travel medicine is the first emerging field in this area. It is defined as the branch of medicine that specializes in travel related diseases and conditions, and their management. ${ }^{2}$ The terminology of travel medicine has been used interchangeably with travel health or travelers' health. In fact, travel health has wider focuses than travel medicine because it also covers the preventive aspects. ${ }^{3}$ Other terms that have also created confusion are health tourism and medical tourism. Health tourism is defined as a business or industry related to traveling activities for the main purpose of getting treatment, improving health and fitness. Whereas, medical tourism is one form of health tourism, which is travelling to get treatment for specific medical conditions such as dental treatment, in-vitro fertilization, hip replacement, and other medical services, where such procedures in the origin countries are much more expensive. There are also other terms such as wellness travel or wellness tourism, where the main purpose of visit is attaining fitness and wellness physically, psychologically, and spiritually. ${ }^{4}$

In a wider perspective, the term of tourism health and healthy tourism have emerged. However, to date, there is no clear definition in academic literatures of such emerging field in public health. Considering the terms and definitions in the field of tourism and travel medicine or health, tourism health can be defined as a branch of public health sciences that deals with various aspects of traveler's health and public health at tourism areas including all parties related to tourism industry. Healthy tourism is the impact that is expected from the implementation of tourism health measures. Furthermore, healthy tourism will also involve all public health principles and practices, including health impact assessment at tourism destinations. ${ }^{5}$
The main driven would be the economic consideration, where unhealthy tourism will suppress tourism industry and decrease host community's economic status. In contrast, healthy tourism initiatives can be employed to promote tourism at destinations.

Some important issues to note if we look at this concept are the need to identify health and safety hazards, assess health and safety risks, related to travel and activities associated with tour packages. This can be used as basis for preventive and promotive approaches to eliminate or reduce risks before and during travel. Considering that most of the risks can be predicted, developing effective and efficient preventive measures can pose new challenges.

Other challenges are fulfillment of medical and public health workforces that have capabilities and competencies in travel health. Synergy between tourism industry and health professionals is a key component, and each party needs to understand its own roles and responsibilities, as well as how ideal interaction needs to be discussed together with all stakeholders.

In general, the tourism industry has three basic components, namely suppliers of travel services, tour operators, and retail travel agents. Included in the travel service suppliers are transportation service providers (air, land, sea), accommodation (hotels, motels, inns), and restaurants. Tour operators are generally in the form of business entities that provide travel packages, while travel agent is a business entity that promotes and sells services provided by suppliers and operators. ${ }^{6}$ The travel bureaus can act as an operator as well travel agents, including providing tour guide services.

As a profession that deals directly with tourism activities, tour guides also have an important role. Tour guides are generally provided by guide services which also coordinate freelance tour guides to meet the needs of individual tourists or the needs of travel bureaus. In carrying out its business, guide services are required to keep paying attention to the professionalism requirements. In addition, the tour guide service providers is required to hire guides who have met the applicable skills requirements and continuously make efforts to improve the skills of the guides concerned. In this case, there is a good opportunity to insert learning materials about health risks at tourism areas. 
Travel agents theoretically can play a major role in the efforts to prevent health problems among tourists. The first is its role in terms of providing information on whether or not the vaccination certificate, related to legal aspects in visiting a region, is needed. For example the need for a certificate of meningitis vaccination to visit Saudi Arabia. Another role is in providing vaccination recommendations that are necessary for the prevention of certain diseases. For example, during a rabies outbreak in Bali, travel agents can convey the importance of rabies pre-exposure vaccination before arrival. Or while already in Bali, travel agents can provide information on what to do if bitten or scratched by animals that have the potential to transmit rabies. In addition, chemoprophylaxis can also be delivered to tourists at risk of contracting a disease, but can be prevented with the provision of certain drugs. For example, tourists visiting West Nusa Tenggara, or other eastern Indonesia, may be advised to consult a doctor to get preventive medication. ${ }^{6}$

Travel agents and tour guides can also be utilized in providing advice related to general health situations in a region at certain times. As dengue fever increases, for example, travel agents can provide information on related preventive measures such as the necessary protection when doing outdoor activities. Travel bureaus can also play a role by providing various media such as potential health risk brochures in tourist destinations, ${ }^{7}$ in coordination with travel agents and tour guides, including conveying the importance of travel insurance, repatriation information and medical service conditions in the tourist destinations.

Travelers are an epidemiologically important population, because they have high mobility and rapidly move from one tourist destination to another. ${ }^{8}$ They have potential exposure to illness and unwanted events outside the place of origin, so that sometimes mild cases are rarely reported and rarely seek treatment . Looking at these characteristics, there is the possibility of importing the disease to the place of origin and, vice versa, the possibility of exporting the disease to the destination. This will increase the risk of changes in endemicity of diseases of non-endemic areas. This suggests that the epidemiology of travel-related diseases is one of the basic competencies that must be possessed by practitioners of medicine and public health in tourist destinations.

Although economically, the increase in the number of international tourists has a positive impact, but this trend will also be followed by an increase in travel-related health risks. A study shows that half of international travelers who come to developing countries will experience health problems related to travel. ${ }^{9}$ The GeoSentinel ${ }^{10}$ data on returned travelers seeking treatment also provides an overview of common health problems in travelers. Doctors in primary and secondary services, especially in tourist areas have an important role in case management, starting from accurate diagnosis and prompt case management. To improve anamnesis capability, practicing physicians in tourist areas should have adequate travel medicine competencies, referring to the basic travel health competencies set by the International Society of Travel Medicine (ISTM) in "The Body of Knowledge for the Practice of Travel Medicine". The curriculum framework is also developed for other professions such as nurses, and other travel health practitioners. ${ }^{11}$

In addition to doctors and nurses, other health professions, especially public health professionals in tourist areas also have enormous potential to be involved. In this case, some additional competencies required are the ability to understand the important elements of disease prevention and the specific disease incidence among travelers, understand the travel health promotion aspect, and be able to conduct a health impact assessment, as well as be able to perform hazard identification, risk assessment, and determination of control (HIRADC) in tourist areas. Furthermore, public health professionals are expected to have good understanding regarding the various types of vaccinations and prophylaxis related to travel.

Last but not least is the interaction between the various professions in the health sector especially doctors, nurses, and public health experts. This inter-professional collaboration coupled with cross-sectoral collaboration with the tourism sectors, including the government and the tourism industry, will play a major role in the realization of tourism health efforts in accordance with the concepts described in this article. If this can work well, a vision for healthy tourism can be a reality.

\section{REFERENCES}

1. Government Regulation No 67/1996 on Organization of Tourism. Indonesia, 1996.

2. Steffen R, DuPont HL. Manual of Travel Medicine and Health. Hamilton, Ontario: BC Decker Inc, 1999.

3. DuPont HL, Steffen R. Textbook of Travel Medicine and Health. 2nd ed. Hamilton, London: B.C Decker Inc., 2001.

4. Horowitz MD, Rosensweig JA, Jones CA. Medical tourism: globalization of the healthcare marketplace. MedGenMed 2007; 9: 33.

5. Wirawan IMA. Kesehatan Pariwisata: Aspek Kesehatan Masyarakat di Daerah Tujuan Wisata [Tourism Health: Public Health Aspects at Tourist Destinations]. Arch Community Heal 2016; 3: ix-xiv.

6. Schiff AL. Travel Industry and Medical Professionals. In: DuPont HL, Steffen R (eds) Textbook of Travel Medicine and Health. Hamilton, London: B.C Decker Inc., 2001, pp. 11-13. 
7. Provost S. Evaluation of a public health newsletter intended for travel agents. J Travel Med 2003; 10: 177-184.

8. WHO. International Health Regulations 2005. 2nd ed. Geneva: World Health Organization, 2008.

9. Reid D, Keystone JS, Cossar JH. Health Risks Abroad: General Considerations. In: DuPont HL, Steffen R (eds) Textbook of Travel Medicine and Health. Hamilton, London: B.C Decker Inc., 2001, pp. 3-9.

10. Leder K, Torresi J, Libman MD, et al. GeoSentinel surveillance of illness in returned travelers, 2007-2011. Ann Intern Med 2013; 158: 456-68.
11. ISTM. Body of Knowledge for the Practice of Travel Medicine - 2012 by Physicians, Nurses and Other Travel Health Professionals. International Society of Travel Medicine.

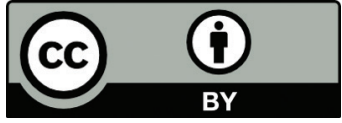

This work is licensed under a Creative Commons Attribution 